\title{
Bishop Paul Verryn's pastoral response towards unaccompanied refugee minors
}

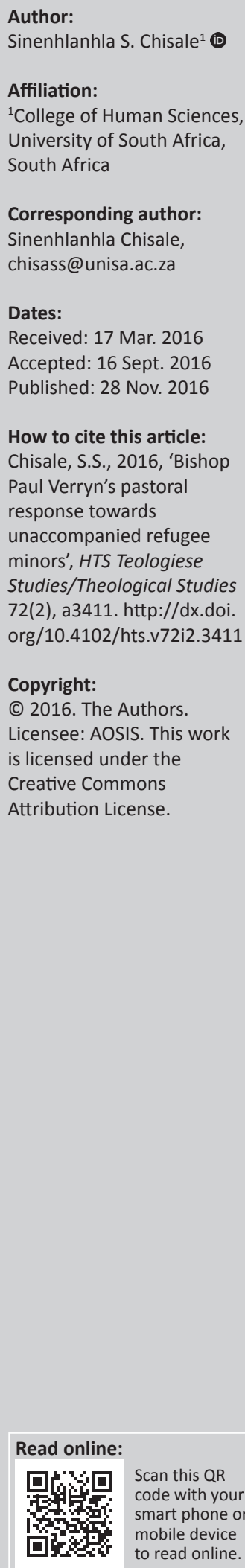

Bishop Paul Verryn is a South African Methodist Church liberation theologian known for his concern for human rights and human dignity. In this article, I acknowledge his response to children and youth migrants in practical theology, general mission studies and pastoral care. I conceptualise Bishop Verryn's response towards Unaccompanied Refugee Minors (URMs) and explore how he weaves pastoral care into the mission of the church. The study from which this article draws followed an exploratory design. Data were collected through structured in-depth interviews, informal conversations with Bishop Verryn and observations. Written from a contextual theology perspective, the findings indicate that Bishop Verryn's pastoral care approach towards URMs is worthy to be developed and recognised as a form of pastoral care and mission work for the broader church's pastoral ministry towards URMs in Africa and abroad.

\section{Introduction}

The aim of this study is to critically examine Bishop Paul Verryn's approach of pastoral care towards Unaccompanied Refugee Minors (URMs) ${ }^{1}$ under his care at the Central Methodist Church (CMC) in Johannesburg. Bishop Verryn has been a minister in the Methodist Church since the age of 21. He was consecrated as a bishop in 1997 and served as Bishop of the Central District of the Methodist Church in Southern Africa, where he filled the role of Superintendent Minister (Hankela 2014:143). In 2010, he was suspended for 3 months from his position as bishop and from his station as minister and superintendent of the Johannesburg circuit. But he remained an ordained minister within the Methodist Church (Kuljian 2013:266). This gave him the opportunity to continue with his work in the church. As part of his ministry in the CMC, Bishop Verryn has served in different ministries, including the Refugee Ministry (Hankela 2014:198). It is his view that faith must have a concrete impact on people's lives 'through transforming reality instead of simply being a plaster that offers a temporary remedy' (Hankela 2014:149). Thus, churches should be responsive to people's social needs by offering a permanent solution to their struggles. This article seeks to contribute to the theological academic discourse by examining and conceptualising Bishop Verryn's approach of pastoral care towards URMs in the Central Methodist Church in central Johannesburg and the Methodist Community Centre in Soweto.

The church's missionary vocation is grounded on the 'participation in God's cosmic purposes for a new order of relationships at all levels in the universe governed by justice, love, peace, and grace' (Langmead 2013:69). The flock of refugees, particularly URMs, to South African churches exposed the strengths, weaknesses and relevance of the mission and pastoral care ministry in these churches. The broader church was divided, with some exhibiting ambivalence in their responses especially to URMs in South Africa. Though some churches welcomed and worked with refugees in Johannesburg, the most visible was the CMC under the leadership of Bishop Verryn. However, Bishop Verryn's pastoral response to URMs is neither researched nor acknowledged as a form of responsive theology that can be developed in guiding the broader church's pastoral care ministry. There is therefore a lacuna in African theories of pastoral care towards URMs. The migration crisis that has affected the global community challenges the broader church through faith to take initiative in her active partnership with God in restoring hope to the migrant community (Bosch 2010:389).

1.In this study, Unaccompanied Refugee Minors are children under the age of 18 who cross the border alone, without parents or adults to care for them. These children are separated from both parents and their extended families and some are orphans seeking refugee status in South Africa. This study will use the abbreviation 'URMs' to refer to these unaccompanied minors from Zimbabwe in South Africa. 
This article draws on my doctoral study (see Chisale 2014). The study followed a qualitative approach, based on an exploratory design. The data are based on a 2-hour structured interview and a series of informal conversations with Bishop Paul Verryn during November 2011 and October 2012. The data also include captions from some of Bishop Verryn's sermons during the period in question, as well as in-depth interviews, participant observations and narrative interviews with URMs and their caregivers during the same period. I accompanied Bishop Verryn to numerous meetings in order to verify some of the issues emerging from the interviews and observations. Some of the data come from participant observations and field notes of Bishop Verryn's pastoral care ministry towards URMs residing in the Soweto Community Centre and Central Methodist Church services with refugees. All the above-mentioned data were analysed through Braun \& Clarke's (2006) six-step thematic analysis.

Some literature on Bishop Verryn's ministry tends to dwell on his theological and philosophical focus (Bompani 2015; Hankela 2014; Kuljian 2013). For my purpose in this article I shall focus on his ministry from anthropological, developmental and pastoral care initiatives. I shall tease out his pastoral care approach with a view to linking it to the church's broader mission towards URMs. The article is written from a contextual theology point of view. It is divided into four sections. I start off by discussing the theological framework of the study and how it applies to the article. Secondly, I present and discuss Bishop Verryn's ministry, starting by exploring the symbolic meaning of the CMC building to refugees, particularly URMs. I shall argue that the CMC building had both positive and negative symbolic meanings to URMs. In this section, emergent trends of Bishop Verryn's approach shall be presented and discussed. Thirdly, I shall discuss how Bishop Verryn integrates his pastoral care ministry into the broader mission of the CMC. In the fourth and final section I shall thread together some central assumptions of Bishop Verryn's pastoral care and offer some concluding remarks.

\section{Theological positioning}

The analysis of results for this study was conducted through the lens of contextual theology. The term contextual theology describes the process of relating the gospel or scripture to a specific context. Bate (1998:152) describes contextual theology as an attempt to reflect upon the experience of faith which is lived in a particular context. In this article, I apply Bevans' (2009) definition of contextual theology as:

\footnotetext{
a way of doing theology that takes into account, or ... puts in a mutually critical dialogue, two realities ... that of Scripture ... [and] the experience of the present or a particular context ... [that] consists of one or more of at least four elements: personal or communal experience, 'secular' or 'religious' culture, social location and social change. (Bevans 2009:9)
}

Here 'contextual' implies linking, connecting or relating theology to experiences of people. It informs this article in that it relates the Word of God to the current situations of people in order for the Word to be relevant. The critical point of contextual theology is for theologians and pastors to take the lives of people seriously given that 'good theology keeps the church in touch with reality' (Matheny 2011:xv). There is no one prescribed way of interpreting Scripture (ibid). Different contexts call for different interpretations. Hence, it is necessary to respond in new and transformed ways to questions of what Christian living means in situations such as those of the refugee crisis. God speaks to current circumstances through contextual theology, and in contextual theology God lives, speaks and takes sides - particularly with the poor referred to as 'preferential option of the poor' (Gutiérrez 1997). The weakness of contextual theology is that it can be oppressive if a context is forced onto people's lives. Furthermore, it depends on who defines the context and the motive of the definer.

\section{Findings and discussion}

In this section I focus on seven emergent trends from the study, namely:

- pastoral care and migration

- the symbolic nature of the CMC

- protection of the child's future through education

- protection of the dignity of URMs

- compassion and solidarity between locals and foreigners

- conscientising URMs about gender issues and HIV

- pastoral care and the broader mission of the Church.

\section{Pastoral care and migration}

According to Lee (2010), churches should be encouraged to establish a caring ministry for immigrants. He cites the Bible to support this view: 'You shall not oppress a foreigner, for you know the heart of a foreigner, because you were foreigners in the land of Egypt' (Ex 23:9; Lee 2010:167). Lee's concern about pastoral care ministry for migrants is crucial in that the Central Methodist Church (CMC) in Johannesburg responded to the above biblical call by establishing a pastoral care ministry that is relevant and responsive to refugees by opening its doors to welcome all refugees, including URMs, and giving hope to the hopeless.

\section{The symbolic nature of the Central Methodist Church as a welcoming place}

The flocking of URMs to the CMC building meant that they had contextualised their suffering and believed that they might find answers in a church. According to Bishop Verryn:

some of the URMs came to the church building because you know the church herself has a symbolic pastoral meaning ... that of love, healing and peace ... these children have been failed by everyone ... therefore the church seems to be a place of hope for them. (pers. comm., 14 June 2012)

Traditionally the church building has a symbolic meaning for the poor and suffering. Bishop Verryn explained that it is not the first time the $\mathrm{CMC}$ in Johannesburg has been a refuge for needy people. He explained that he became aware of the homeless people at a time when the South African Council of 
Churches (SACC) offices were bombed in 1988. He indicated that the offices were bombed at a time when a Catholic priest was calling for a ministry to support the poor and address the plight of the homeless and destitute in inner city Johannesburg. As a result, the Central Methodist Mission responded by establishing Paballo Ya Batho (caring for the people). According to Bishop Verryn, this led to more people coming to the CMC for support. He explained that many people:

who came to seek for assistance were from outside Johannesburg and some were from outside South Africa. As a result they were very vulnerable so we decided quite conservatively to open the doors ... because the church should be welcoming to all. (pers. comm., 14 June 2012)

Bishop Verryn defines the symbolic meaning of the CMC as a welcoming place that is easily accessible.

But the symbolic meaning of the church was gendered for URMs. Boys and girls defined the symbolic meaning of the church from their experiences as outlined by Chisale (2014). Though they all hoped that the CMC would be a place where they could find 'love, grace, mercy and care of God' (Chisale 2014:162), often the CMC building was contrary to their expectations. Initially, before interventions and criticisms by various stakeholders, particularly the media, URMs were mixed with adult refugees in the CMC building, although on separate floors from the adults. Their security was compromised with some girls experiencing sexual abuse and bullying by adult refugees and URM boys experiencing bullying, participating in gangs and engaging in high-risk sex with adult refugees for survival (Chisale 2014:167-168). As a result, the symbolic meaning of the CMC building for URMs was the exact opposite of what they had anticipated. This was acknowledged by Bishop Verryn who stated that the reason they moved the URMs to Soweto Community Centre was because they were not safe in the CMC building. This implies that the symbolic meaning of a church and church building can be regarded as contradictory. The positive symbolic meaning for the URMs was that they were discovered by Bishop Verryn who then worked for their security and well-being in South Africa.

Kieckhefer (2014:155) explains that the symbolic meaning of a church is realised because people enter a 'shared world of symbolic narratives and meanings, somewhat like entering into a story and discovering the richness and internal coherence of its structure'. The church building has a symbolic meaning of welcoming and refuge; its fittings and adornments represent a sense of sacredness (Kieckhefer 2014:135). 'Removing the CMC from its current scenario to its original form, one can tell that it was a state of architecture with many rooms in a six-floor building' (observations made during data collection 2011-2012). My observations confirmed that in his drive to accommodate refugees into the CMC building, Bishop Verryn wanted to send a message about the symbolic nature of the church building. He said:
How can you have a church empty when people sleep in the streets vulnerable to all sorts of evil ... at first we started with a maximum of about 50 people then of course it multiplied until today where everywhere you walk in this building somebody sleeps. (pers. comm., 14 June 2012)

The reference to an empty church while people sleep on the streets indicates that empty churches that do not consider accommodating the needy are preaching an irrelevant gospel. Reeves (1996:170) laments the emptiness of the church in America and argues that the reason is that the church is 'unappealing and socially irrelevant'. For the gospel to be relevant to people, contextual theology maintains that it should speak and respond to peoples' experiences.

The church is generally portrayed as a place of refuge and peace in some films (Andrews 2014:44), particularly in contexts of war, poverty and suffering. The belief is that Jesus - in his suffering, crucifixion and resurrection symbolises an 'active welcoming' that embraces all people and their differences (Bishop Verryn, sermon 22 April 2012). Hampson (2010:20) reminds us that the Pope has urged 'churches, communities and governments that the notion of Christian welcome and hospitality is to be applied to migrants and refugees, even those deemed to [be] "illegal"'. Hampson pleads for human dignity to be prioritised over human law of a country. Bishop Verryn identified the tensions that exist between South African laws and respect for human dignity as a challenge to the pastoral care ministry and argued that the problem lies in people being self-centred (interview 14 June 2012).

In opening doors to refugees, Bishop Verryn said he believed in human agency and respect for human dignity over the human law. This indicates that his ministry focused on socioeconomic justice. Hankela (2014:151) describes Bishop Verryn's theological vision as centred in the reality of poverty and socio-economic inequality. Bishop Verryn's ministry embraces the suffering of URMs by standing up as their active representative among both religious and secular authorities. The following priorities emerge from Bishop Verryn's pastoral care ministry towards URMs: protect the child's future through education; protect the dignity of URMs by advocating for their rights; advocate for compassion and solidarity between locals and foreigners; and teach children and youth about issues of gender, puberty, sex, sexuality and HIV and AIDS. I will discuss each of these in turn.

\section{Protection of the child's future through education}

According to Bishop Verryn, the church cannot ignore the significance of education to all humanity. He explains that:

when a child is in a crisis, hungry, naked and without shelter you cannot say, may God bless you and keep you, then allow that child to go without attending his or her physiological needs. (pers. comm., 14 June 2012)

For Bishop Verryn, the church's calling to pastoral care is to empower and liberate the poor, weak and vulnerable 
human beings. Often the church focuses on satisfying spiritual and physiological needs of humanity separately, and struggle to strategically weave the two as Christ did. His constant use of the 'image of God' theme in his sermons and conversations seems to be at the core of his praxis. $\mathrm{He}$ laments the injustices of the world towards children and argues: 'It is a social and structural sin to the image of God' (pers. comm., 14 June 2012).

The concept of 'structural sin' has its origins in the Latin American liberation theology of the 1960s and 1970s and was originally used to describe the dehumanising conditions experienced by that continent's poor. For Bishop Verryn, the plight of refugees is a sin that is 'institutionalised and systematised' (pers. comm., 14 June 2012). Thus, in protest against this sin, he sees human liberation and empowerment of refugees - particularly URMs - through education as being one of the many possible solutions. According to him, '[f]aith is not faith if it does not respond to the poor, marginalised, victims and vulnerable such as URMs' (pers. comm., 14 June 2012).

In responding to the needs of the vulnerable, Bishop Verryn prioritised education. Education is a tool of liberation from oppression or dehumanisation (Freire 1970). However, I interpret Bishop Verryn's use of the term as similar to Nelson Mandela's reference to it 'as the most powerful weapon which you can use to change the world'. For Bishop Verryn, education that is liberating can help to eradicate the total dependence of refugees.

His views on education can be linked to the Freirean perspective. The idea of introducing a primary and a secondary school, an infant day care centre, an adult basic education training centre, a preschool, and an adult education and vocational training centre has links to Paulo Freire's perspective of praxis-oriented education (Freire 1970). For Bishop Verryn, education should liberate people by encouraging them to reflect critically on their experiences (conversation outside interviews on 22 April 2012). His idea of pastoral care for refugees, particularly URMs, is:

Christ and Christ's love and commandment to love one another as he has loved us. (pers. comm., 14 June 2012)

To love one another is to make sure that another person's future is certain by liberating and empowering that person to be able to sustain him- or herself. This ensures that a person receiving pastoral care experiences the true visionary dimension of the responsive love and grace of God. When he spoke about education, he first used the commonly used Confucian principle of poverty alleviation, namely: 'give a man [sic] a fish and you feed him [sic] for a day. Teach a man [sic] to fish, and you feed him [sic] for a lifetime' (Yuan 2014). He viewed education as lifetime liberation for refugees. He seemed proud of the academic performance of $\mathrm{O}$ and $\mathrm{A}$ level students. He proudly announced that Albert Street School for refugees teaches the Cambridge syllabus and writes Cambridge examinations, competing with prestigious schools in South Africa that are writing Cambridge examinations. The O level class of 2011 came first in the international Cambridge Examinations with a $94 \%$ pass rate, making the Albert Street School the top school offering Cambridge O levels (interview 14 June 2012). Due to the high unemployment rate in South Africa and URMs' native countries Bishop Verryn said he encourages refugees to take studies that will enable them to employ themselves (interview 14 June 2012).

\section{Protection of the dignity of URMs by advocating for their rights}

In his efforts to protect the dignity of URMs, Bishop Verryn fought for their rights as children in his pastoral care and mission work. Those who had difficulties with their identity documents were assisted to apply for study and work permits as well as asylum-seeker permits using their birth names and surnames. A name and surname is crucial for human beings, indigenous Africans in particular, as this defines them and, at the same time, promotes their dignity (Charles \& Linwood 1973). The dignity of humans is linked to their humanity. Bishop Verryn observed that migration sometimes dehumanises people and may cause confusions and uncertainties about the future. His concern for the humanisation of refugees seems to be linked to Saayman's (2007) understanding of humanisation. According to Saayman (2007:5) humanisation is critical, because this is what Christ's mission is about. Thus, Bishop Verryn saw the humanisation and dignity of URMs at the centre of his ministry. For URMs to be humanised, Bishop Verryn campaigned for them to be legalised in South Africa. This form of pastoral care takes the lived experiences of people seriously (Streets 2014). The legalisation of URMs in South Africa, according to Bishop Verryn, is the first step towards protecting their dignity; it enabled them to access social services within the country (conversation with Bishop Verryn, 18 June 2012). In our interview and conversations, he demonstrated advanced knowledge of the Constitution of South Africa, the South African Children's Act and other international instruments, meant to protect children, to which South Africa is a signatory. Therefore, he weaved these instruments in his pastoral care approach towards URMs' dignity. He carefully linked his response to the country's constitution and defended his response to refugees, not only from a biblical perspective, but from a constitutional and human rights perspective too.

\section{Compassion and solidarity between locals and foreigners}

In an informal conversation (10 May 2012), Bishop Verryn expressed concern about the hatred and discrimination that exists in South Africa among foreigners and locals. To him it complicates the integration of refugees into local communities. Further, although the idea of integrating refugees into communities is excellent, the process of integration is poorly strategised, negotiated and managed (interview 14 June 2014). Speaking of xenophobia among URMs, he said he integrated abandoned South African children with URMs from other countries. For him, this was somehow an antidote 
to xenophobia, because children can learn to accept, love and appreciate each other regardless of their different nationalities (pers. comm., 14 June 2012). He then introduced the family approach, where caregivers took the role of parents in guiding children; the division of children by nationality was deconstructed. Observations and field notes confirm that the family setting deconstructed the binary opposition in South Africa between foreigners and citizens. Caregivers represented absent parents for URMs and South African abandoned children. In my observation, this enhanced cohesion in the community.

Literature conceptualises xenophobia through the politics of inclusion and exclusion (Jearey-Graham \& Böhmke 2013). The politics of inclusion or exclusion is observed as the cause of xenophobia between nationals and foreigners in South Africa (ibid). Research identifies the politics of exclusion/inclusion as a legacy of colonialism and apartheid (Neocosmos 2010:88). Thus, the church is assumed to be the best platform to condemn xenophobia by preaching love for one another (Awasu \& Awasu 2012:8). The virtue of love as preached by the church is not just accepting the stranger in their communities and spaces, but also welcoming and embracing each other despite differences in nationalities. The message of love, welcoming, hope and embracing each other was central to Bishop Verryn's sermons. In the first devotion that I attended with URMs in the Soweto Community Centre, Bishop Verryn reminded them about the presence of God in their situations. His preaching focused on God's provision for the poor (sermon 18 March 2012, 7pm). It is the love that calls for local South Africans and foreign nationals to be in solidarity with each other.

\section{Bishop Verryn regards love as a virtue:}

that points to the very heart of the Christian witness of faith in the world and encourages us ... to actively seek out and delight in the well-being of others, even if it means sacrificing our own well-being and perhaps our lives for others. (pers. comm., 14 June 2012)

Bishop Verryn must have been driven by love to acknowledge what Lartey (2003) observes as pluralism in the context of URMs and to understand their culture, social context and origins (cf. Sturm 1998:41). His pastoral care approach critically explores the contextual realities of URMs and is parallel to Swart and Yates' (2006:331) observation of the virtue of love in a ministry to children. For Bishop Verryn, Christ is love and, as Christ's disciples, the church should be urged by love to take action against the suffering of others. He contextualised his sermons to the experiences of refugees. He showed up-to-date knowledge of the politics and divisions among refugees because he stayed with them, listened to their conversations and worshipped with them.

\section{Conscientising URMs about gender issues and HIV}

Bishop Verryn explained that it is crucial and significant to conscientise URMs about the challenges of puberty by teaching them about the dangers and benefits of sex and sexuality, since they do not have adults or parents to teach them (interview 14 June 2012). Adolescents are categorised among the vulnerable in connection to HIV prevalence (Naswa \& Marfatia 2010; cf. Chisale \& Buffel 2014). Bishop Verryn thus explained that they arrange seminars and invite professionals to teach URMs about HIV and AIDS. According to Bishop Verryn, URMs are conscientised about issues of puberty, how to understand themselves sexually and how to respect one another sexually (interview 14 June 2012). For Bishop Verryn, caregivers are 'hands on' with URMs; they guide them on issues of puberty and sex, responsibility and moral behaviour (interview 14 June 2012). In his view:

pastoral care is all about being transparent when it comes to issues of gender, sexuality, puberty, sex and HIV and AIDS, so that humanity will experience the love of God. (pers. comm., 14 June 2012)

As much as migration brings with it positive, life-changing patterns, such as job opportunities, better health and better education, it also exposes children to abuse, exploitation and HIV and AIDS (Chisale 2014). Thus, Bishop Verryn encouraged caregivers in the Soweto Community Centre to shape and influence URMs' behaviour (Chisale \& Buffel 2014:289) and Bible studies were used in this community to address radical issues that confuse URMs, particularly relating to sex, sexuality, gender and HIV and AIDS (observations made in Soweto Community Centre 30 June 2012 and 29 September 2012). Observations and interviews with caregivers indicate that the family setting idea enabled them to nurture and apply their indigenous knowledge in shaping and influencing URMs' behaviour.

They introduced indigenous rites of passage to accommodate URMs' cultural beliefs. Research has taught that childhood is a critical age for deconstructing dangerous gender constructions (Chisale 2014). Targeting the behaviour of URMs in deconstructing gender stereotypes was emphasised in this community by Bishop Verryn, who observed this age as vulnerable (conversations with Bishop Verryn 12 August 2012). Caregivers used the African proverb isikhumba sigoqwa sisemanzi, meaning human behaviour and attitudes are shaped early in childhood. The family setting is a good space for deconstructing oppressive gender stereotypes among children and for teaching children about right and wrong behaviour. This was not the case in the Soweto Community Centre according to my observations and field notes: some oppressive rites of passage were used in efforts to shape the sexual behaviour of children (Chisale \& Buffel 2014). The caregivers used the family space to actively nurture traditional and oppressive gender stereotypes and roles. On the other hand, good sexual behaviour was taught in this community; many boys and girls valued their virginity status. This is critical in delaying sexual debut among children and youth.

Issues of sexual diversity were taught in order to help URMs to accept each other. However, this seemed difficult for some URMs and caregivers, who reacted strangely to issues of 
homosexuality (observations made in Soweto Community Centre). The reason could be that the majority of URMs and caregivers were from Zimbabwe where sexual diversity is questioned and sexual orientation is criminalised if the person is lesbian, gay, bisexual, transgender, queer or intersex (LGBTQI). Observations confirmed that, although URMs from Zimbabwe were struggling to understand LGBTQI, they were tolerant; they trusted Bishop Verryn, so his teaching was well received and implemented. One might argue that they would not have bitten the hand that feeds them. This could be true because their well-being depended on Bishop Verryn and some URMs saw him as their 'saviour' (Chisale 2014).

I find Bishop Verryn's approach to pastoral care contextual and responsive to the needs of URMs, because it is child-centred. It removes 'dependency syndrome', 'victim syndrome' and initiates a 'survival syndrome' through advocating for praxis-oriented and prestigious education. Theologically, his approach promotes and protects the dignity of URMs and restores hope for a better life beyond their struggles.

\section{Pastoral care and the broader mission of the Church}

Pastoral care is often treated as a mini-mission of the church, constricted within the church's sacraments and liturgics. This narrow interpretation of pastoral care affects how the church executes her ontological responsibility on earth (Simut 2007). It is crucial to acknowledge that 'pastoral care forms a vital part of the church's mission' (Avis 2005:42). Bishop Verryn clearly reflects this in his pastoral response to URMs and refugees. He weaves pastoral care and the church's mission together in order to humanise, liberate and empower URMs. He does not treat these church responsibilities separately, but sees them as strengthening each other. Bishop Verryn juxtaposes pastoral care to the mission and ministry of the church in order to continue Christ's redemptive work on earth. His ministry takes the side of the poor in contexts of injustice and oppression. Thus, it is action-oriented (praxis), as theory alone cannot humanise an oppressed person, but praxis can lead people to recover their lost humanity (Freire 1970:44). The focal point of his ministry is humanising and protecting the dignity of the oppressed refugees. In order to humanise URMs, Bishop Verryn has developed a 'childcentred' pastoral response that puts the future of the child as the focal point of humanisation. He combines pastoral care and mission as means to an end of faith. For Paul Verryn pastoral care is positioned in the broader theological context of mission. The CMC as a sent church (mission) uses pastoral care to drive Christ's mission on earth proactively.

In contextualising his pastoral response, Bishop Verryn prioritises the context of the refugees in his interpretation of the gospel, because 'good theology keeps the church in touch with reality' (Matheny 2011:xv). Though a Wesleyan, Bishop Verryn leans more towards John Calvin's theology by weaving together Calvin's humanist pastoral response and the Wesleyan theology of social justice and applying these to the situation of refugees who come to South Africa. On merit, Bishop Verryn takes pastoral care out of the pastor's office and the congregant's home to a radical dimension where ministry takes the social justice dimension.

Previously, Bishop Verryn claimed to be influenced by theologians such as Karl Barth and Dietrich Bonhoeffer (Hankela 2014:144), but a critical analysis of his ministry to URMs shows greater affinity to Calvin's response to Protestant European refugees (Rodriguez 2015). Calvin's focus was not only to reform the church, but also society and public life (De Gruchy 2010:373). His 'pastoral care became not only a refuge for the persecuted Protestants, but also a beacon for reformers throughout Europe who came to Geneva to learn under Calvin in order to replicate his successes back home ...' (Rodriguez 2015:47). Calvin recognised the skills of refugees and guided them in using their skills to make a decent living (Duchrow 2009:86). Parallel to Calvin, Bishop Verryn believes 'there is no dogma without ethics and no ethics without practical ministry' (Hankela 2014:149), particularly in a context of suffering and poverty. For him society is built on solidarity and compassion; hence he provided a 'safe haven' for refugees. Responsive pastoral care from the church is able to face and condemn any life-threatening condition from a gospel perspective. Bishop Verryn's pastoral response to URMs in South Africa represents a long-awaited paradigm shift post-democracy in the Christian ministry towards refugees. It is clear from his pastoral response that the Christian ministry goes beyond baptism, preaching, evangelisation and charity work. For church ministry to be effective and responsive, churches should intervene in the socio-economic and political spheres. This is Christ-centred ministry, which is concerned about the well-being of humanity (Avis 2005). In relation to URMs, Bishop Verryn conscientises us that pastoral care should stand in solidarity with children, struggle with them, suffer with them as well as enjoy salvation with them. By weaving pastoral care into the broader mission of CMC, Bishop Verryn takes the lost psyche of a child to a safe healing space where the love and grace of God is experienced unconditionally.

\section{Bishop Verryn's central assumptions of pastoral care and conclusion}

Bishop Verryn's pastoral response towards URMs is a challenge to the world-wide church to revisit its pastoral care and mission ministry. Bishop Verryn's ministry exhorts us to prioritise children's education. Action-oriented pastoral care prioritises the sustenance of life and, in the 21st century, education is critical. His ministry prioritises relevant and purposeful education. Children's education in particular should not stop because of a crisis they may be going through; on the contrary, wherever children are and whatever their life crisis, they still need education. Bishop Verryn's ministry prioritises high quality education as crucial in helping URMs find purpose in life. The curriculum offered in Albert Street School for URMs has a significant potential of advancing learners' critical thinking skills and increasing their zeal to 
succeed in life. The skills training centre offers training that responds to the current high unemployment contexts. The vocation centre trains refugees to be innovative entrepreneurs. Learners are educated to be self-employed rather than to depend on being employed. Evidence of skills training can be ascertained by the prevalence of small businesses owned by foreign nationals in Gauteng, particularly in Johannesburg and Pretoria. It is worth noting that Bishop Verryn's prioritisation of education among URMs has offered young girls and boys from poverty-stricken families the opportunity to access good education. Girls who may otherwise have been constrained within traditional gender roles have benefited from the high quality education offered to URMs in Albert Street School. His contextualised approach to pastoral care takes a radical interpretation of Scripture. Rather than applying Scripture to URMs' context, Bishop Verryn considers Scripture and URMs' experiences in tandem. If Christ came so that all may have life to the fullest (Jn 10:10), then the church needs to be innovative and creative in order to help fulfil Christ's promise. According to De Gruchy (2001), Christians have developed creative and innovative ways to respond to those in need. Churches that are not innovative and creative in their pastoral responses towards those in need are not worthy to be sent on a mission of Christ. However, at times creativity may weaken the message of Scripture and unwittingly perpetuate illegal migration.

Bishop Verryn's protection of URMs' dignity through fighting for their rights is important for their well-being. An obstacle that affects URMs is the Department of Home Affairs' legalisation process. The consequence of being illegal in any country is deportation, which leads to struggle. The legalisation of URMs in South Africa, either through asylum permits or study permits, makes it easy to empower them. Legalisation enhances their dignity since they can access social services. Bishop Verryn's ministry is centred in the image of God; in God there is no 'othering'. His knowledge of the country's constitution, international, regional and domestic instruments meant to protect human dignity play a critical role in his pastoral care approach particularly in taking an active initiative.

Bishop Verryn's advocacy for compassion and solidarity between foreigners and South Africans is at the heart of the church's pastoral and mission ministry. Xenophobia, tribalism and racism are obstacles to the cohesion and development of any society. If Christ is love, then xenophobia is a sin. In helping URMs to realise the love and redemptive work of Christ through the church, Bishop Verryn applied innovative solutions, such as integrating URMs from outside South Africa with South African abandoned children. For him this is an antidote to xenophobia. When children live as a family they see each other as family members: they are united by their shared narratives, meanings and experiences of distress and their striving for emancipation. The symbolic nature of family as a place of love, nurturing, struggles, politics, divisions and unity is a safe space for cohesion. Thus, the integration of refugees into communities can be a solution to xenophobia if properly negotiated and managed as in a family context.
Sexuality and sex are still considered as a taboo and because of this adolescents are confused and vulnerable to HIV and AIDS. Bishop Verryn uses pastoral care and mission work to target the social and sexual behaviour of URMs. In some indigenous African contexts, children go through the rites of passage and are taught about responsible social and sexual behaviour through these ceremonies. Bishop Verryn uses the idea of a family to teach URMs about safe sex and high-risk sex. Bible studies gave URMs space to interrogate their challenges from a scriptural perspective. I was fascinated by the Bible studies because URMs themselves served as facilitators and participants. The URMs interpreted the Bible from their own personal experiences. However, their naive interpretations of Scripture often seemed confused.

Bishop Verryn's approach does not necessary follow a particular order of priority. It does not cover all the actions of Bishop Verryn to URMs. I chose specific themes as a starting point for this article. While Bishop Verryn's ministry might have some gaps, in this article I sought to advocate its pastoral care upshot. As a result I largely adopted a positive view of his ministry among URMs. It is my conviction that Bishop Verryn's approach could be developed for the broader church's pastoral and missionary ministry to URMs in Africa and abroad.

\section{Acknowledgements Competing interests}

The author declares that she has no financial or personal relationships which may have inappropriately influenced her in writing this article.

\section{References}

Andrews, E., 2014, Place, setting, perspective: Narrative space in the films of Nann Moretti, Fairleigh Dickinson University Press, Madison, WI.

Avis, P., 2005, A ministry shaped by mission, T\&T Clark International, London.

Awasu, C. \& Awasu, C., 2012, 'Giving sanctuary: Church-based social capital and Zimbabwean refugees in South Africa', African Journal of Social Science 2(4), 1-13.

Bate, S.C., 1998, 'Method in contextual missiology', Missionalia 26(2), 150-185.

Bevans, S., 2009, 'What has contextual theology to offer to the church of the 2st century?', Mission Lecture 15 October, Church Mission Society Oxford, viewed 11 November 2011, from http://www.cmsuk.org/DesktopModules/Bring2mind/ DMX/Download.aspx?DMXModule $=410 \&$ Command=Core_Download \& language $=$ en-US\&Entryld $=2390 \&$ Portalld $=2 \&$ Tabld $=81$

Bompani, B., 2015, 'Local religious organisations performing development: Refugees in the Central Methodist Mission in Johannesburg', Journal of International Development 27(2), 197-212. http://dx.doi.org/10.1002/jid.2900

Bosch, D.J., 2010, Transforming mission: Paradigm shifts in theology of mission, Orbis, Maryknoll, NY.

Braun, V. \& Clarke, V., 2006, 'Using thematic analysis in psychology', Qualitative Research in Psychology 3(2), 77-101. http://dx.doi.org/10.1191/1478088 706qp063oa

Charles, J. \& Linwood, S., 1973, Boys and girls names, Harrap, London.

Chisale, S.S., 2014, 'Pastoral care with children in a context of HIV and AIDS: Towards a contextual pastoral care model with Unaccompanied Refugee Minors (URMs) from Zimbabwe in the Methodist Church Community Centre in Johannesburg', Unpublished DTh thesis, University of South Africa, Pretoria.

Chisale, S.S. \& Buffel, O., 2014, 'The culturally gendered pastoral care model of women caring for refugee girls in a context of HIV/AIDS', Studia Historiae Ecclesiasticae 40(suppl.), 285-303.

De Gruchy, J.W., 2010, 'John Calvin, Karl Barth and Christian humanism', NGTT 51(suppl.), 370-378.

De Gruchy, S., 2001, 'Thinking mission: Is development really worth it?', Inside Out 20, CWM, London, viewed 15 March 2010, from http://www.cwmission.org.uk/ 
Duchrow, D., 2009, “'Calvin's understanding of society and economy”, in Theology out of the context in honour of Dr. C.S. Song', Theologies and Cultures 6(2), 58-97.

Freire, P., 1970, Pedagogy of the oppressed, Penguin, Harmondsworth.

Gutiérrez, G., 1997, 'Renewing the option for the poor', in D. Batstone, E. Mendieta, L.A. Lorentzen \& D.N. Hopkins (eds.), Liberation theologies, postmodernity and the Americas, Routledge, London.

Hampson, J., 2010, 'JRS accompaniment - A new way of being present?', Grace \& Truth: A Journal of Catholic Reflection of Southern Africa 27(2), 15-28.

Hankela, E., 2014, Ubuntu, migration and ministry: Being human in a Johannesburg church, Brill, Leiden.

Jearey-Graham, N. \& Böhmke, W., 2013, "AA lot of them are good buggers": The African "foreigner" as South Africa's discursive Other', Psychology in Society 44, 21-41.

Kieckhefer, R., 2014, Theology in a stone: Church architecture from Byzantium to Berkeley, Oxford University Press, New York.

Kuljian, C., 2013, Sanctuary: How an inner-city church spilled onto a sidewalk, Jacana Media (Pty) Ltd., Auckland Park.

Langmead, R., 2013, 'What is missiology?', Missiology: An International Review 42(1), 67-79. http://dx.doi.org/10.1177/0091829613480623

Lartey, E., 2003, In living color: An intercultural approach to pastoral care and counseling, 2nd edn., Jessica Kingsley Publishers, London.

Lee, T.-Y., 2010, 'The loss and grief in immigration: Pastoral care for immigrants', Pastoral Psychology 59, 159-169. http://dx.doi.org/10.1007/s11089-009-0261-3

Matheny, P.D., 2011, Contextual theology: Drama of our times, Pickwick Publications, Eugene, OR.
Naswa, S. \& Marfatia, Y.S., 2010, 'Adolescent HIV/AIDS: Issues and challenges', Indian Journal of Sexually Transmitted Diseases 31(1), 1-10. http://dx.doi.org/ 10.4103/0253-7184.68993

Neocosmos, M., 2010, From 'foreign natives' to 'native foreigners': Explaining xenophobia in post-apartheid South Africa, citizenship and nationalism, identity and politics, CODESRIA, Dakar.

Reeves, T.C., 1996, The empty church: The suicide of Liberal Christianity, Free Press, New York.

Rodriguez, R.R., 2015, 'Reformed: Calvin's legacy of compassion: A Reformed theological perspective on immigration', in M.D.R Carrol \& L.A.M. Sanchez (eds.), Immigrant neighbours among us: Immigration across theological traditions, Pickwick Publications, Eugene, OR.

Saayman, W., 2007, Being missionary being human: An overview of Dutch Reformed mission, Cluster Publications, Pietermaritzburg.

Simut, C.C., 2007, The ontology of the church in Hans Küng, Peter Lang AG, Bern, Switzerland.

Streets, FJ, 2014, 'Love: A philosophy of pastoral care and counselling' Verbum et Ecclesia 35(2), Art. \#1323, 1-11. http://dx.doi.org/10.4102/ve.v35i2.1323

Sturm, D., 1998, 'On the suffering and rights of children: Toward a theology of childhood liberation', in D. Sturm (ed.), Solidarity and suffering: Toward a politics of relationality, pp. 39-61, State University of New York Press, Albany, NY.

Swart, I. \& Yates, H., 2006, 'The rights of children: A new agenda for practical theology in South Africa', Religion and Theology 13(3\&4), 314-340. http://dx.doi. org/10.1163/157430106779024635

Yuan, T., 2014, 'Diploma serves diplomacy: China's "donor logic" in educational aid', China: An International Journal 12(2), 87-109. 